\title{
Polyphasic taxonomy of green algae strains isolated from Mediterranean freshwaters
}

\author{
Urania Lortou and Spyros Gkelis ${ }^{*}$ (i)
}

\begin{abstract}
Background: Terrestrial, freshwater and marine green algae constitute the large and morphologically diverse phylum of Chlorophyta, which gave rise to the core chlorophytes. Chlorophyta are abundant and diverse in freshwater environments where sometimes they form nuisance blooms under eutrophication conditions. The phylogenetic relationships among core chlorophyte clades (Chlorodendrophyceae, Ulvophyceae, Trebouxiophyceae and Chlorophyceae), are of particular interest as it is a species-rich phylum with ecological importance worldwide, but are still poorly understood. In the Mediterranean ecoregion, data on molecular characterization of eukaryotic microalgae strains are limited and current knowledge is based on ecological studies of natural populations. In the present study we report the isolation and characterization of 11 green microalgae strains from Greece contributing more information for the taxonomy of Chlorophyta. The study combined morphological and molecular data.
\end{abstract}

Results: Phylogenetic analysis based on $18 \mathrm{~S}$ rRNA, internal transcribed spacer (ITS) region and the large subunit of the ribulose-bisphosphate carboxylase $(r b c L)$ gene revealed eight taxa. Eleven green algae strains were classified in four orders (Sphaeropleales, Chlorellales, Chlamydomonadales and Chaetophorales) and were represented by four genera; one strain was not assigned to any genus. Most strains (six) were classified to the genus Desmodesmus, two strains to genus Chlorella, one to genus Spongiosarcinopsis and one filamentous strain to genus Uronema. One strain is placed in a separate independent branch within the Chlamydomonadales and deserves further research.

Conclusions: Our study reports, for the first time, the presence of Uronema in an aquatic environment up to $40^{\circ} \mathrm{C}$ and reveals new diversity within the Chlamydomonadales. The results from the ITS region and the rbcL gene corroborated those obtained from $18 \mathrm{~S}$ rRNA without providing further information or resolving the phylogenetic relationships within certain genera, due to the limited number of ITS and $r b c L$ sequences available. The comparison of molecular and morphological data showed that they were congruent. Cosmopolitan genera with high worldwide distribution inhabit Greek freshwaters.

Keywords: Chlorophyta, Chlorophyceae, Freshwater, Molecular systematics, Multi-gene phylogeny, Trebouxiophyceae, Greece

\section{Background}

All green algae and embryophyte plants belong to Viridiplantae which were divided early into two evolutionary discrete lineages: the Chlorophyta and Streptophyta [1]. Chlorophyta are an ancient, morphologically and ecologically diverse lineage that include three major classes: Ulvophyceae, Trebouxiophyceae, Chlorophyceae (UTC)

*Correspondence: sgkelis@bio.auth.gr

Department of Botany, Aristotle University of Thessaloniki, P.O. Box 109, 54124 Thessaloniki, Greece
[2] and the majority of described species of green algae [1]. Approximately 8000 Chlorophyta species have been described, whilst it is estimated that at least 5000 species still remain undescribed [3]. Despite the fact that the diversity of Chlorophyta is being studied for a long time, our knowledge for their taxonomic and phylogenetic relationships is still deficient [4]. Microscopic green algae are mainly identified based on specific morphological traits (general shape of the cells, position of chloroplasts, presence of pyrenoids, type of reproduction, colony formation, flagella, ultrastructural characteristics etc.) [1]. 
Nevertheless, morphological identification of microalgae can be very tough due to the absence of obvious structural features in most species and the high degree of variability of several of the observable characteristics within species $[5,6]$. The morphological species concept is very subjective, thus the phylogenetic species concept or diagnostic concept [7] has gained a lot of ground [8-10]. As summarized by Krienitz and Bock [11] higher taxonomic lineages such as divisions, classes and orders have been totally revised since molecular phylogenetic methods were introduced into the taxonomy of green algae. Molecular phylogenetic evidence has provided a substantially improved understanding of the relationships among major lineages.

Molecular diversity and phylogeny of isolated members of Chlorophyta derived from Mediterranean freshwaters is a relatively unexplored area; most of the existing studies investigate the ecological status of freshwaters, including morphological identification of microalgae [12-14]. Data on isolation and combined morphological and molecular characterization of Chlorophyta strains are limited and mainly focused on their biotechnological potential $[15,16]$. Greece is probably the most diverse Mediterranean country with an excessive level of diversity and endemism of species [17] and it is not rare that new taxa are discovered in animal [18] and microalgal phyla $[19,20]$. However, the phylogenetic relationships of Chlorophyta in Greece are barely known as the available information is derived almost exclusively from morphological and/or ecological studies of natural populations $[21,22]$. This study investigates the diversity of green algae (Chlorophyta) strains isolated from freshwaters in Greece using a polyphasic approach including morphology, $18 \mathrm{~S}$ rRNA, ITS, and $r b c L$ phylogeny.

\section{Results}

Eleven strains were isolated from surface water samples collected from six lakes (Doirani, Karla, Kastoria, Koronia, Pamvotis, and Volvi) and one hot spring (Agkistro) located in Greece (Table 1). Three morphotypes of Chlorophyta were identified using light microscopy; six strains corresponded to Desmodesmus-like species, four strains were coccoid, and one filamentous (Figs. 1, 2). According to morphology (Table 2) and phylogenetic analyses of $18 \mathrm{~S}$ rRNA (Fig. 3), the 18S-28S ITS region (Fig. 4) and $r b c L$ gene (Fig. 5), the isolated strains were placed into clades within the Chlorophyceae and Trebouxiophyceae.

Based on 18S rRNA phylogeny (Fig. 3), the strains TAUMAC 0810, 2810, 3110 and 3410 were clustered together into the Sphaeropleales group, within Desmodesmus; strains 2810 and 3410 were placed within D. subspicatus and D. communis, respectively, whereas the strains 0810, 3110 were clearly positioned within a separate Desmodesmus subclade comprised of $D$. abundans. In the order Chaetophorales, strain TAU-MAC 0215 was placed into the Uronema clade. Strains TAU-MAC 3510, 3310 and their allied taxa form a separate independent branch within the Chlamydomonadales; 3510 formed a subcluster with a Chlorococcum strain and 3310 formed a well-supported ( 0.99 posterior probability) clade which contains a total of four OTUs: the studied strain, two isolates characterized as "Chlamydomonad sp." ( $\geq 99.9 \%$ similarity) and one strain of the new genus and species Spongiosarcinopsis terrestris. A direct comparison of sequence similarities among the strains 1110, 3210 and Chlorella vulgaris showed a $99 \%$ sequence identity. Nevertheless they formed a distinct subclade inside Chlorella vulgaris clade (Fig. 3). The well-supported relationships for strains TAU-MAC 0810, 1110, 2810, 3110, 3210, 3410, 0215 identified in the $18 \mathrm{~S}$ rRNA analysis were also found

Table 1 Green algae strains isolated in this study and their origin

\begin{tabular}{|c|c|c|c|c|c|}
\hline \multirow[t]{2}{*}{ Strain (TAU-MAC) } & \multirow[t]{2}{*}{ Origin } & \multicolumn{2}{|c|}{ Geographic coordinates } & \multirow[t]{2}{*}{ Habitat } & \multirow[t]{2}{*}{ Collection date } \\
\hline & & (N) & (E) & & \\
\hline Uronema sp. 0215 & Agkistro hot springs & $41^{\circ} 22^{\prime} 04^{\prime \prime}$ & $23^{\circ} 25^{\prime} 40^{\prime \prime}$ & Benthic & 20/10/2015 \\
\hline Spongiosarcinopsis sp. 3310 & Lake Doirani & $41^{\circ} 18^{\prime} 56^{\prime \prime}$ & $22^{\circ} 45^{\prime} 37^{\prime \prime}$ & Planktic & $21 / 8 / 2010$ \\
\hline Desmodesmus communis 3410 & & & & Planktic & $21 / 8 / 2010$ \\
\hline Chlorella vulgaris 3210 & Lake Karla & $39^{\circ} 28^{\prime} 29^{\prime \prime}$ & $22^{\circ} 51^{\prime} 33^{\prime \prime}$ & Planktic & 10/8/2010 \\
\hline Desmodesmus abundans 0810 & Lake Kastoria & $40^{\circ} 31^{\prime} 11^{\prime \prime}$ & $21^{\circ} 15^{\prime} 47^{\prime \prime}$ & Planktic & 26/8/2010 \\
\hline Desmodesmus sp. 1010 & Lake Koronia & $40^{\circ} 42^{\prime} 04^{\prime \prime}$ & $23^{\circ} 08^{\prime} 17^{\prime \prime}$ & Planktic & $30 / 3 / 2010$ \\
\hline Chlorella vulgaris 1110 & & & & Planktic & $15 / 6 / 2010$ \\
\hline Desmodesmus abundans 3110 & & & & Planktic & $15 / 6 / 2010$ \\
\hline Desmodesmus subspicatus 2810 & Lake Pamvotis & $39^{\circ} 40^{\prime} 51^{\prime \prime}$ & $20^{\circ} 50^{\prime} 30^{\prime \prime}$ & Planktic & $1 / 11 / 2010$ \\
\hline Chlamydomonadales sp. 3510 & & & & Planktic & $1 / 11 / 2010$ \\
\hline Desmodesmus sp. 0910 & Lake Volvi & $40^{\circ} 40^{\prime} 37^{\prime \prime}$ & $23^{\circ} 33^{\prime} 10^{\prime \prime}$ & Planktic & $12 / 7 / 2010$ \\
\hline
\end{tabular}



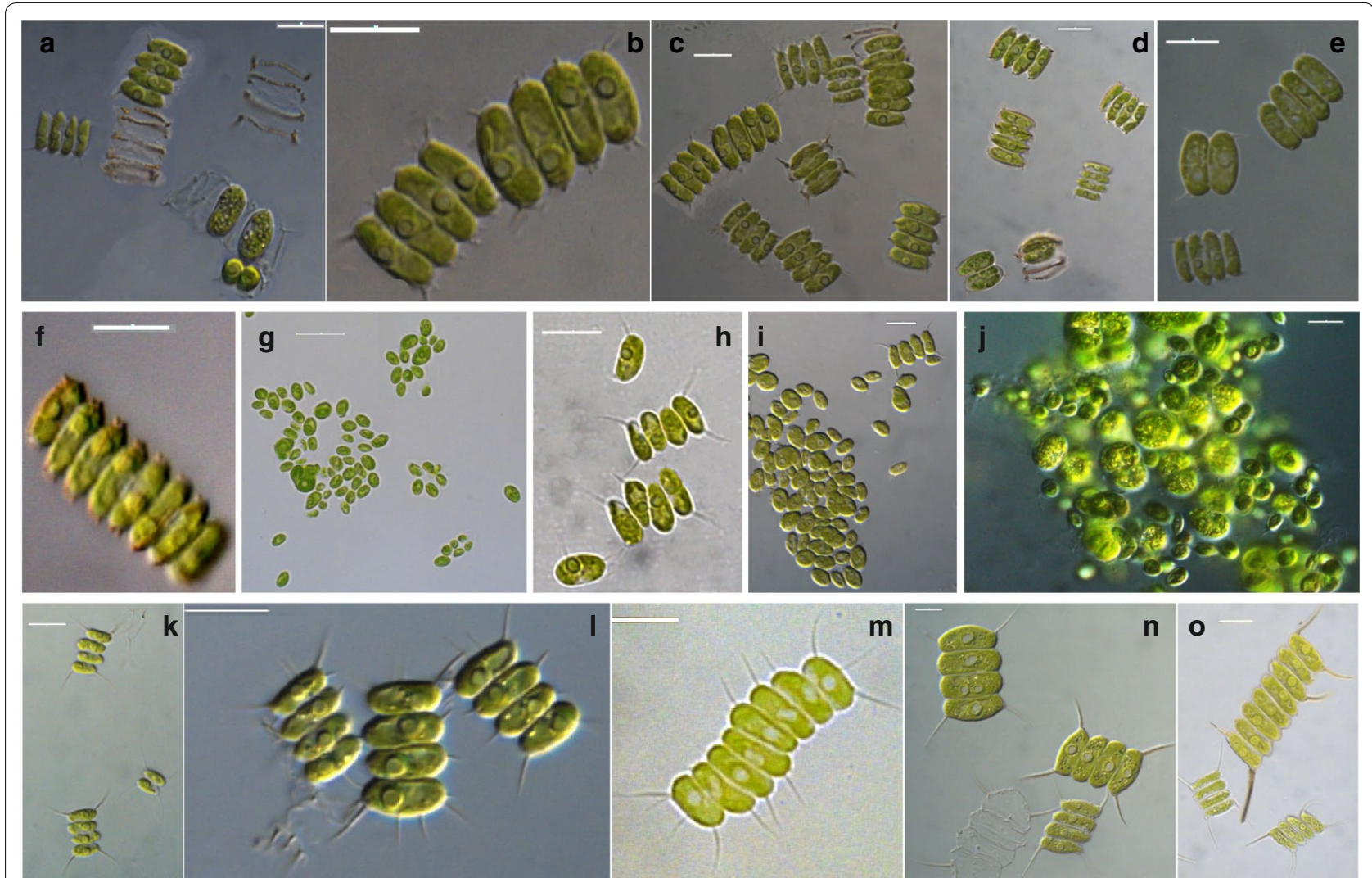

m
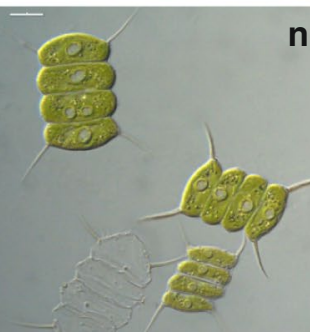

n 0

Fig. 1 Microphotographs of strains TAU-MAC 0810, 0910, 1010, 2810, 3410 under light microscopy. a-c Desmodesmus sp. TAU-MAC 0910 and d-f TAU-MAC 1010 demonstrating mature and young coenobia with polar and lateral spines; $\mathbf{a}, \mathbf{c}, \mathbf{d}$ autosporangia, $\mathbf{a}$, $\mathbf{d}$ cell wall ornaments observable from cell wall residues, $\mathbf{f}$ eight-celled coenobium. $\mathbf{g}-\mathbf{i}$ Desmodesmus abundans TAU-MAC 0810 and $\mathbf{j}, \mathbf{k}$ TAU-MAC 3110; coenobia with polar and lateral spines, unicells and aggregation forms. I, $\mathbf{m}$ Desmodesmus subspicatus TAU-MAC 2810; coenobia with lots of lateral spines. $\mathbf{n}$, o Desmodesmus communis TAU-MAC 3410. Bars, $10 \mu \mathrm{m}$

in the ITS phylogeny (Fig. 4). Strains 0910, 1010 formed a clade with unidentified Desmodesmus species. The closest relative of strain 3310 based on the ITS region, with 96\% identity, was a Balticola (MH068690.1) sequence. Sequences from $r b c L$ regions were successfully amplified and sequenced only for fours strains: TAU-MAC 0810, 1110, 3210, and 3410. Molecular data based on $r b c L$ just corroborated the results coming from $18 \mathrm{~S}$ rRNA and ITS phylogenies: strain 0810 formed a subclade with an unidentified species within $D$. abundans clade, 3410 clustered within D. communis clade and isolates 1110, 3210 clustered together with Chlorella vulgaris sequences (Fig. 5). The different tree construction methods produced similar trees.

The morphology of Desmodesmus-like strains corresponded to Desmodesmus as all of them had spines, in contrast to Scenedesmus spp. which have a smooth, nonornamented cell wall. The morphological and morphometric characteristics of each strain are given in Table 2. Under light microscopy coenobia of the strains TAUMAC 0810 and 3110 were always spined with two polar and one lateral spine in the outer cells (Fig. 1g-k), a common trait of Desmodesmus abundans. The morphology of the strain TAU-MAC 2810 was similar to Desmodesmus subspicatus; coenobia were four-celled and always with lots of spines both in outer and inner cells (Fig. 1l, $\mathrm{m})$. Strain TAU-MAC 3410 matched the morphological structure of Desmodesmus communis; four-celled coenobia bearing four corner spines on the end cells of colonies (Fig. 1l, m). Strains TAU-MAC 0910 and 1010 exhibited intermediate structures to $D$. abundans and $D$. communis but with shorter subpolar and lateral spines and were classified as Desmodesmus sp. (Fig. 1a-f). Under light microscopy, strains TAU-MAC 1110 and 3210 were the classical "green balls", tiny, solitary-living and simply propagating spherical microalgae (Fig. 2i-n), matching the morphological description of Chlorella vulgaris. Coenobia of the strain TAU-MAC 3310 were organized into dyads, tetrads, or packets resulting from desmoschisis (Fig. 2o-r), as in the recently described genus Spongiosarcinopsis; species discrimination was not possible due to lack of data. The strain TAU-MAC 3510 exhibited 

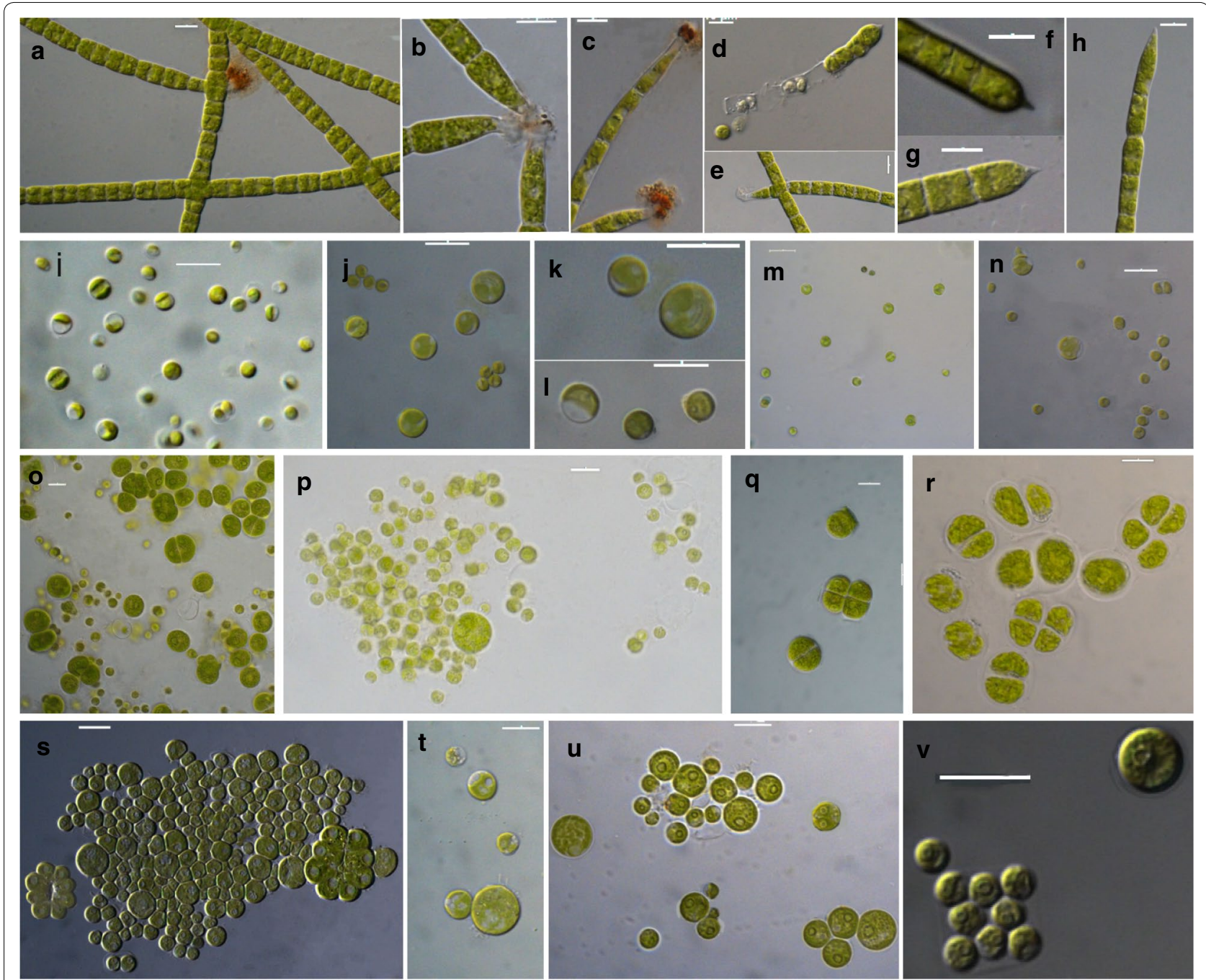

Fig. 2 Microphotographs of strains TAU-MAC 0215, 1110, 3210, 3310, 3510 under light microscopy. a-h Uronema sp. TAU-MAC 0215; a-c, e different morphologies of the holdfast, $\mathbf{d}$ release of aplanospores, $\mathbf{f}-\mathbf{h}$ filaments with apical cells showing alterative degree of tapering. $\mathbf{i}-\mathbf{k}$ Chlorella vulgaris TAU-MAC 1110 and I-n TAU-MAC 3210; demonstrating sporangium with two autospores, young and mature cells with one big pyrenoid. o-r Spongiosarcinopsis sp. TAU-MAC 3310; $\mathbf{0}$, p young vegetative cells derived from zoospores or aplanospores, aplanospores and aplanosporangium, $\mathbf{q}$, $\mathbf{r}$ mature vegetative cells arranged in dyad and tetrad aggregation. $\mathbf{s}-\mathbf{v}$ Chlamydomonadales Sp. TAU-MAC 3510; $\mathbf{s}-\mathbf{u}$ mature vegetative cells form tight aggregations, $\mathbf{v}$ autospores

solitary, spherical cells with the ability to form cell aggregates (Fig. 2s-v) but no other characteristic traits or flagella were observed, therefore we could not assign it to any genus of the Chlamydomonadales. Under light microscopy the strain TAU-MAC 0215 displayed morphological traits of the genus Uronema; filaments uniseriate, unbranched, attached to substratum by holdfast, bearing a pointed apical cell at the free end (Fig. 2a-h). For most of the strains, the comparison of molecular and morphological data showed that they were congruent. Interestingly, both morphology and phylogeny placed the strain TAU-MAC 3510 within the Chlamydomonadales, but provided insufficient evidence to identify a genus.

\section{Discussion}

In this study we report for the first time the isolation and polyphasic taxonomy of freshwater green algae strains from Greece belonging to the genera Desmodesmus, Chlorella, Spongiosarcinopsis and Uronema. A small number of Tetraselmis strains have been previously isolated from Greek lagoons [23] but freshwater species have been characterized mainly through microscopic observations [22, 24-27] or molecular cloning of the 
Table 2 Morphometric and morphological characteristics of the TAU-MAC strains isolated from freshwaters in Greece

\begin{tabular}{|c|c|c|c|}
\hline Strain (TAU-MAC) & Description & Figures & Taxonomic assignment \\
\hline 0910, 1010 & $\begin{array}{l}\text { Colonial green algae having flat colonies that consist of two or four cells linearly arranged } \\
\text { along their long axes. Four-celled coenobia most frequent, but also two-celled and } \\
\text { eight-celled were observed. Cell dimensions } 8-14 \mu \mathrm{m} \text { long and } 3-7 \mu \mathrm{m} \text { wide with one } \\
\text { big pyrenoid, short subpolar spines and small lateral. Ribs and rosettes present. Asexual } \\
\text { reproduction by aplanosporogenesis }\end{array}$ & $1 a-f$ & Desmodesmus sp. \\
\hline 0810,3110 & $\begin{array}{l}\text { Cells ovoid and elongated, slightly larger and more elongated in } 0810 \text { than in } 3110 \text {, with } \\
\text { one clearly visible pyrenoid surrounded by a sheath of starch plates. The ellipsoidal cells } \\
\text { had dimensions } 3-9 \times 2-6 \mu \mathrm{m}(0810) \text { and } 2-7 \times 2-5 \mu \mathrm{m}(3110) \text {. The single, spineless cells } \\
\text { were dominant in } 0810 \text { isolate. The rare four-celled coenobia were always spined with two } \\
\text { polar and one lateral spine in the outer cells. Two-celled coenobia were the most frequent } \\
\text { in } 3110 \text { isolate and less commonly four-celled linearly arranged along their long axes. The } \\
\text { coenobia had two polar spines in each outer cell, rarely lateral spines were observed. Sin- } \\
\text { gle cells often had two polar spines. Reproduction by autospores produced by longitudinal } \\
\text { division, two to eight per sporangium }\end{array}$ & $1 g-k$ & Desmodesmus abundans \\
\hline 2810 & $\begin{array}{l}\text { Cells ovoid with single large pyrenoid. The two-celled coenobia were common, but four- } \\
\text { celled coenobia were predominant and always with lateral spines both in outer and inner } \\
\text { cells. Cell dimension 5-13 } \mu \mathrm{m} \text { long and 3-7 } \mu \mathrm{m} \text { wide. Asexual reproduction by aplano- } \\
\text { sporogenesis }\end{array}$ & $11, m$ & Desmodesmus subspicatus \\
\hline 3410 & $\begin{array}{l}\text { Ellipsoidal cells ( } 11-21 \mu \mathrm{m} \text { long and } 3.4-9 \mu \mathrm{m} \text { wide); coenobia linearly arranged with one big } \\
\text { pyrenoid per cell covered with starch envelope. The dominant four-celled and rare eight- } \\
\text { celled coenobia were always spined with one spine at each pole of outer cells. The entire } \\
\text { coenobium was surrounded by an outermost cell wall layer which is visible between poles } \\
\text { of inner cells of coenobia. Coenobia with lateral spines in inner cells ware observed very } \\
\text { rarely. Asexual reproduction by division of mother cell into } 4 \text { daughter cells }\end{array}$ & $1 \mathrm{n}, \mathrm{o}$ & Desmodesmus communis \\
\hline 0215 & $\begin{array}{l}\text { Filaments unbranched and indefinite in length. Cells are cylindrical, elongated, closely adher- } \\
\text { ent to one another, uninucleate. Cell diameter increases with the age of a filament from } 4 \\
\text { to } 10 \mu \mathrm{m} \text { and } 7 \text { to } 23 \mu \mathrm{m} \text { long, containing more than one pyrenoid. Most of the filaments } \\
\text { possess a pointed apical cell at the free end which exhibit a different degree of tapering } \\
\text { (acuminate, apiculate or attenuate) and a holdfast for attachment by means of a modified } \\
\text { basal cell. The morphology of the holdfast also varies from small and colorless to massive } \\
\text { and dark brownish-red. The unbranched filaments may undergo fragmentation. Asexual } \\
\text { reproduction takes place by aplanosporogenesis or zoosporogenesis }\end{array}$ & $2 a-h$ & Uronema sp. \\
\hline 1110,3210 & $\begin{array}{l}\text { Cells always spherical and microscopic, 3-9 } \mu \mathrm{m} \text { in diameter with one large pyrenoid. Young } \\
\text { cells ellipsoidal, becoming spherical at maturity. Reproduction by autosporogenesis usually } \\
\text { two autospores per sporangium }\end{array}$ & $2 \mathrm{i}-\mathrm{n}$ & Chlorella vulgaris \\
\hline 3310 & $\begin{array}{l}\text { Ellipsoidal to spherical solitary young cells } 4-9 \mu \text { m in diameter. Each young cell contains one } \\
\text { relatively big nucleus and one pyrenoid covered with starch envelope. Mature cells ovoid } \\
\text { to irregular in shape, } 19 \mu \mathrm{m} \text { in max. dimension, organized into dyads, tetrads, or packets } \\
\text { resulting from desmoschisis. Mature cells remain uninucleate, possessing one to four pyr- } \\
\text { enoids. Asexual reproduction performed by desmoschisis or zoospores and aplanospores }\end{array}$ & $20-r$ & Spongiosarcinopsis sp. \\
\hline 3510 & $\begin{array}{l}\text { Solitary vegetative cells spherical to irregular form, } 7-13 \mu \mathrm{m} \text { diameter with the ability to form } \\
\text { cell aggregates. One or several pyrenoids, single nucleus or multiple nuclei directly before } \\
\text { reproduction by aplanospores. Flagella not visible under the light microscope. Asexual } \\
\text { reproduction by aplanospores }\end{array}$ & $2 s-v$ & Chlamydomonadales sp. \\
\hline
\end{tabular}

$18 \mathrm{~S}$ rRNA gene $[28,29]$. Most of the TAU-MAC strains (0810, 0910, 1010, 2810, 3110 and 3410) belong to the genus Desmodesmus, one of the most abundant genera in fresh to brackish waters all over the globe [30]. Their cosmopolitan occurrence illustrates the wide range of environmental conditions these organisms can tolerate due to the high degree of polymorphism they exhibit [31, 32]. The genus Desmodesmus was separated from Scenedesmus sensu lato based on ITS2 sequences [33] but Desmodesmus species taxonomy remains one of the most long-standing issues in green microalgal systematics [34]. Many of the Desmodesmus strains/species display considerable morphological variability due to nutrient availability, environmental signals and culture conditions [34, 35]. This issue has led to the description of more than 1300 species and sub-specific taxa in the former genus Scenedesmus, of which many are invalid [36]. This is obvious from our phylogenetic trees where, within Desmodesmus clades, not revised sequences previously characterized as Scenedesmus are included (e.g. the sequences AJ249514.1 and X73995.1 which are described as Scenedesmus but actually refer to D. subspicatus and D. abundans, respectively). Strains TAU-MAC 0810 and 3110 were identified as Desmodesmus abundans by 


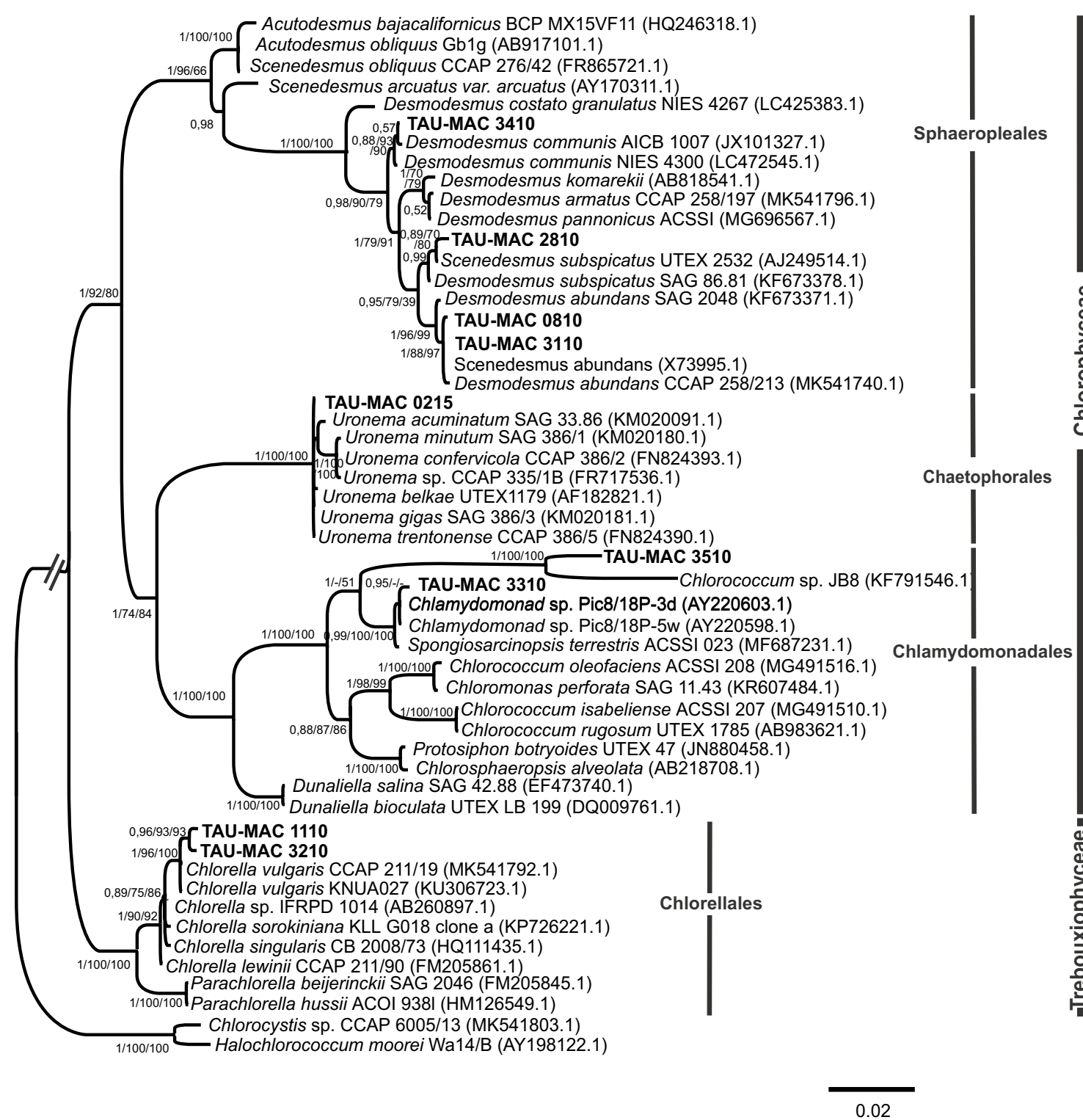

Fig. 3 Bayesian inference (BI) phylogenetic tree of relationships of 185 rRNA (c. $1700 \mathrm{bp}$ ) of green algae strains isolated from waterbodies of Greece, including the classes Chlorophyceae and Trebouxiophyceae. Support values are indicated as posterior probability for BI and bootstrap support for maximum likelihood (ML) and maximum parsimony (MP) analysis (BI/ML/MP). The numbers in parentheses are GenBank accession numbers

molecular and morphological analysis. Because of the extensive morphological variability of the species [37], organisms previously belonging even in different classes (e.g. Chlorella fusca SHIH. et KRAUSS) have been reassessed as D. abundans [37, 38]. Different morphological structures were observed in our cultures also. Molecular phylogenies based on the 18S rRNA and ITS regions placed strain 2810, with very high node support, in a clade with Desmodesmus subspicatus strains isolated from different freshwaters worldwide [38-42]. However, this strain was isolated from the hypertrophic, shallow
Lake Pamvotis where heavy toxic cyanobacterial blooms are frequently formed [43]. Morphological taxonomy was congruent to the molecular classification [35]. Strains TAU-MAC 0910 and 1010 were identified as Desmodesmus as well, since they plainly clustered together with unidentified species of the genus. Phylogenetic analyses could not be conclusive down to the species level as their DNA was amplified only with ITS region primers. Moreover, morphology did not allow species delimitation, owing to morphological criteria we could not point out, due to the phenotypic plasticity of Desmodesmus 


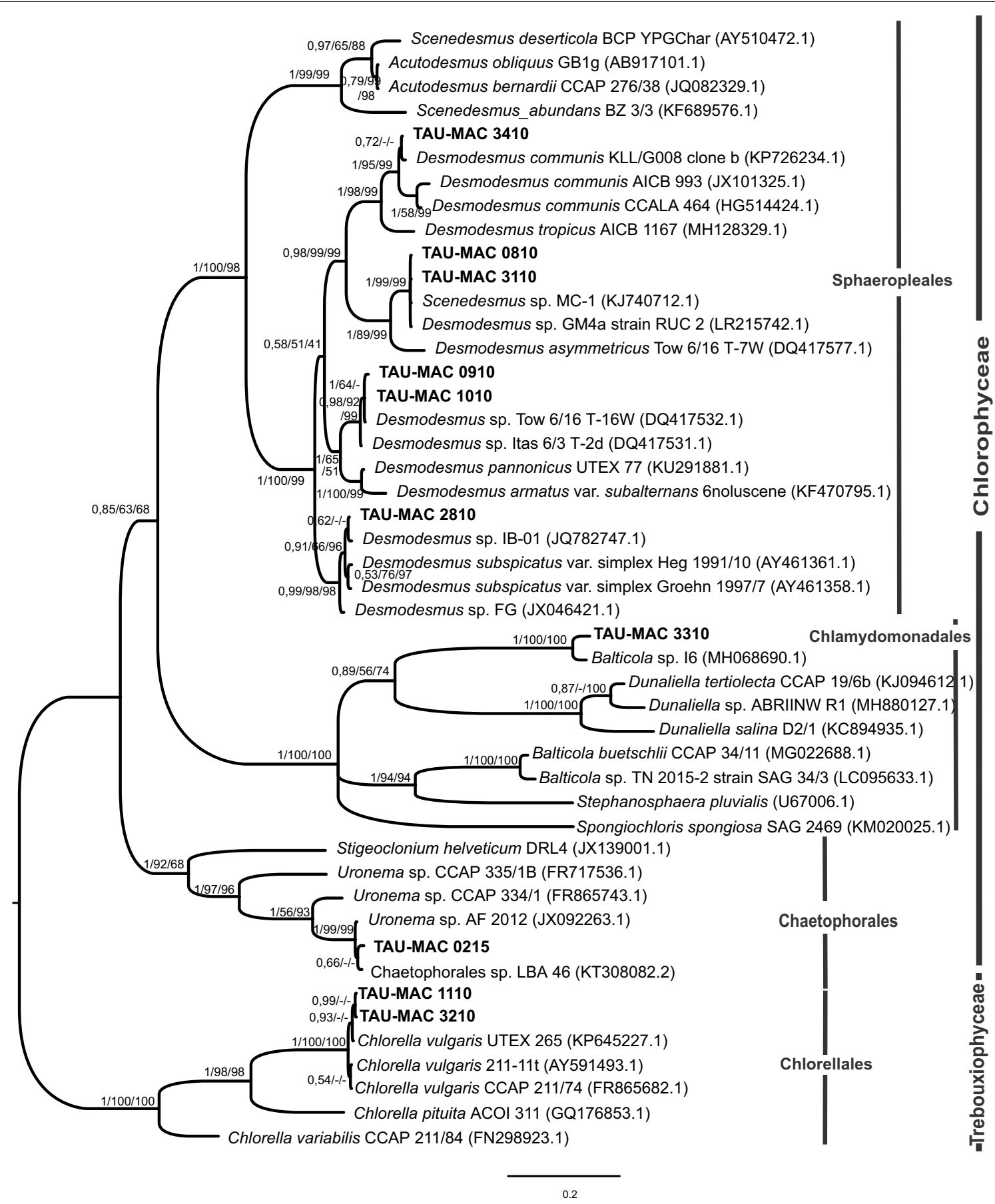

Fig. 4 Bayesian inference (BI) phylogenetic tree of relationships of internal transcribed spacer 1 and 2 (ITS1/TS2) rDNA (c. 700 bp) of green algae including the classes Chlorophyceae and Trebouxiophyceae. Support values are indicated as posterior probability for Bl and bootstrap support for maximum likelihood (ML) and maximum parsimony (MP) analysis (BI/ML/MP). The numbers in parentheses are GenBank accession numbers

and the similarity of structures between Desmodesmus species $[31,44]$. In the $18 \mathrm{~S}$ rRNA and ITS phylogeny all sequences that clustered together into well-supported clades with the strain TAU-MAC 3410 are Desmodesmus communis [also known with the traditional name Scenedesmus quadricauda Turp. (Bréb)], isolated from Europe to Asia [45, 46]. The alignment of these sequences with 3410 showed identity up to $99 \%$. The $r b c L$-based 


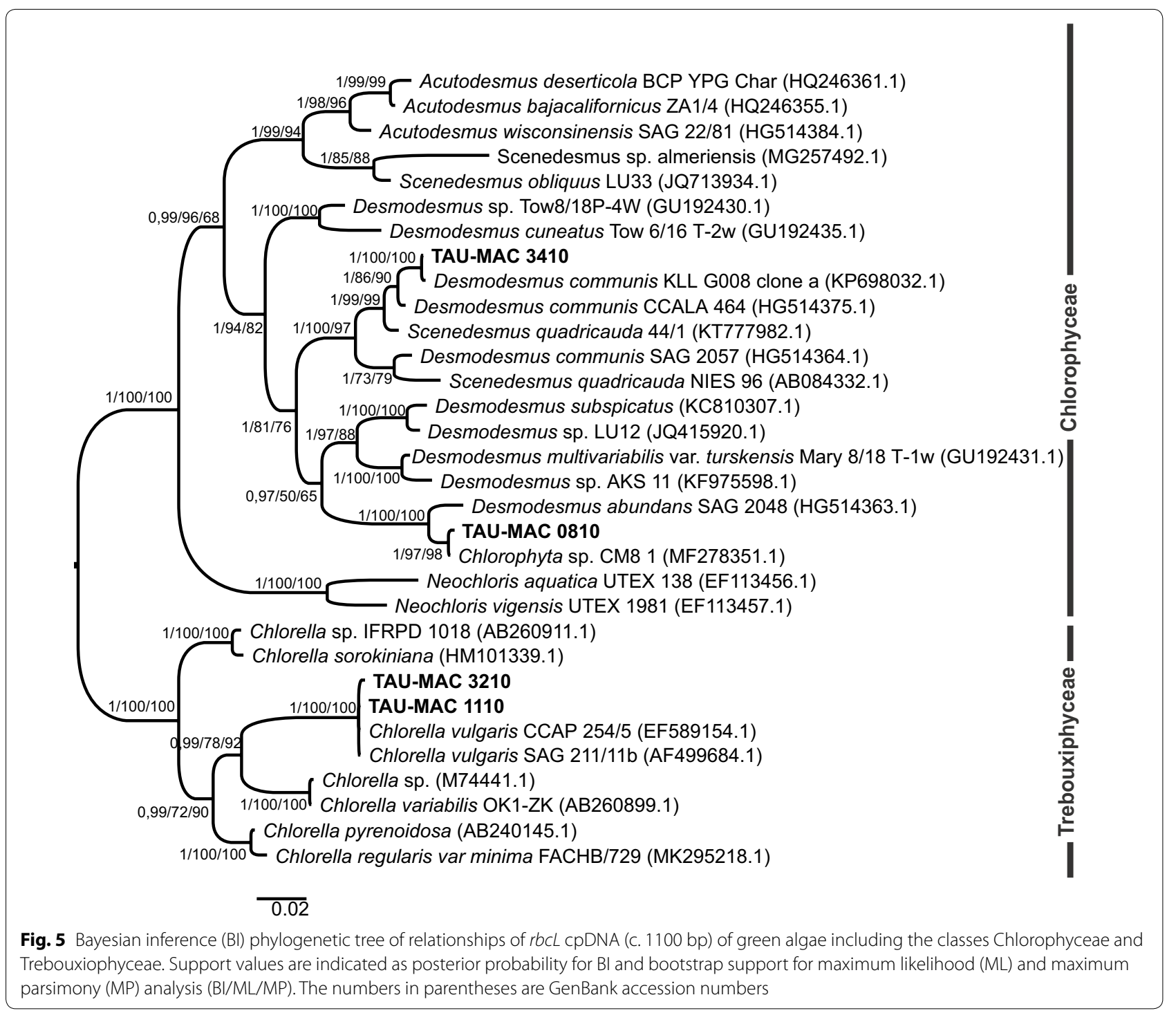

phylogeny supports the previous results, since 3410 clustered together with a Scenedesmus quadricauda sequence [47] probably belonging to a non-revised $D$. communis [45]. Under light microscopy, TAU-MAC 3410 displayed the common structure of the species [46, 48]. The species has a wide distribution in freshwaters, mainly in those with moderate temperature and in the slightly eutrophicated ones [46] but our strain was isolated from Lake Doirani, an extremely eutrophic lake [49]. Species of the genus have been identified in freshwaters of Greece $[21,25,27,50]$.

Greek lakes also host Chlorella vulgaris, the archetypical form of coccoid green algae firstly described by Beijerinck in 1890 [51]. Molecular phylogeny based on three molecular markers placed strains TAU-MAC 1110 and 3210, with high bootstrap values, in clades with Chlorella vulgaris strains isolated from various environments. The microscopic observations merely confirmed the molecular results [51, 52]. Chlorella and its relatives belong to the most common aquatic, terrestrial and aerophytic algae with ubiquitous distribution [53]. The sequences clustering together with TAU-MAC strains originate from different habitats of USA, Europe, New Zealand and Japan, while TAU-MAC strains were isolated from the two hypertrophic Lakes Pamvotis and Koronia [22, 25, 54]. This is the first report of Chlorella vulgaris presence in these lakes. Furthermore, because of its tiny size, population size and physiological ability to tolerate desiccation or other types of abiotic stress, Chlorella has been reported as an air-dispersed microorganism in Greece $[24,55]$. 
The phylogenetic position with maximal bootstrap value of TAU-MAC 0215 isolated from hot springs clustered with representatives of the filamentous genus Uronema. Under light microscopy, the strain exhibited the typical morphological features of the genus [56, 57]. Its $18 \mathrm{~S}$ rRNA sequence showed $99-100 \%$ pairwise sequence identity with all Uronema species included in the clade, whilst in ITS phylogeny the closest relative $(98.2 \%$ similarity) was an unidentified Uronema sequence. Representatives of the genus appear as benthic algae in mesotrophic and eutrophic ecosystems while are common in both terrestrial and aquatic environments $[56,58]$. The strains clustering together with TAU-MAC 0215 have a wide distribution since they are derived from North America to Europe. To the best of our knowledge, this is the first report of the presence of Uronema in an aquatic environment up to $40{ }^{\circ} \mathrm{C}$. Representatives of Uronema in Greece have been previously reported in Lake Amvrakia [59].

The strains TAU-MAC 3310 and 3510 were placed in a separate independent branch within the Chlamydomonadales, the largest group of Chlorophyceae with a complex taxonomic history [1]. Phylogenetic analyses of nuclear and chloroplast DNA sequences have changed the concept of the class: this clade includes a large number of Chlamydomonadales taxa, plus taxa formerly placed in Dunaliellales, Chlorococcales, Tetrasporales, Chlorosarcinales, Volvocales, and Chaetophorales as summarized by Leliaert et al. [1]. The closest $18 \mathrm{~S}$ rRNA sequence to TAU-MAC 3510 was the strain Chlorococcum sp. JB8 isolated from extreme saline-alkali soil in China [60]; however, the low pairwise sequence similarity (96\%) and the lack of other morphological traits suggest that our strain forms a novel clade within Chlamydomonadales. The closest relative of TAU-MAC 3310 with 99\% similarity (18S rRNA) was a strain isolated from a gray forest soil in Russia belonging to the novel, recently described genus and species Spongiosarcinopsis terrestris [61], together with two unclassified representatives of Chlamydomonadales (Pic8/18P-3d and Pic8/18P$5 \mathrm{w}$ ) derived from an eutrophic pond in Itaska State Park, Minnesota [62]. In 18S rRNA phylogeny, 3310 was placed in a well-supported clade with the two isolates mentioned previously, forming a distinct subclade inside the Spongiosarcinopsis clade. Even if the strain displayed similar morphological characteristics to $S$. terrestris, the different niche (aquatic vs. terrestrial) and the separate subclade suggest that our strain together with Pic8/18P$3 \mathrm{~d}$ and Pic8/18P-5w belong to a different Spongiosarcinopsis species and deserve further research. Buchheim et al. [63] studying the phylogeny of the Chlamydomonadales, compared nuclear-encoded small-subunit rRNA sequences and chloroplast-encoded large subunit rRNA sequences from flagellate green algae. Their analyses showed that the chloroplast phylogenies are clearly more robust than the nuclear phylogenies suggesting that the chloroplast data are more variable having a greater density of genetically informative sites than the nuclear data. Unfortunately, the $r b c L$ gene could not be amplified in strains 3510 and 3310. Studies discuss the universality of primers for this marker and they indicate the need to design more efficient and robust primers for a broader coverage of plant species $[64,65]$.

\section{Conclusions}

Polyphasic taxonomy based on three genetic markers (18S rRNA, ITS and $r b c L$ gene) and morphology divulged eight taxa among eleven strains from Greek freshwaters. Most of the strains were identified as Desmodesmus. Some representatives of the genus have already been recognized in Greek freshwaters but this is the first time they are isolated and identified by molecular analyses. Two strains could be assigned to Chlorella vulgaris and this is the first report of its presence in the lakes where they were isolated from. One filamentous strain belongs to the genus Uronema, reported for the first time in an aquatic environment up to $40{ }^{\circ} \mathrm{C}$. Two strains $(3310,3510)$ are placed in a separate independent branch within the Chlamydomonadales indicating novel diversity that deserves further investigation. Green algae isolated from Greek lakes seem to be cosmopolitan and non-toxic. Molecular data from the three genetic markers converged but more submitted sequences are needed to clarify relationships within the genera.

\section{Methods}

\section{Sample collection, isolation and culture}

Strains were isolated from water samples collected from six freshwaters of Greece and from an algal mat in a thermal spring between 2010 and 2015 (Table 1). Water samples were collected from the surface layer $(0-0.5 \mathrm{~m})$ of inshore sites, details are given in Gkelis and Zaoutsos [66]. The algal mat sample was collected after carefully scratching with a sterile scalpel the mat and placing the detached mat in sterile $50 \mathrm{~mL}$ polyethylene vessels. All sampling sites were chosen based on existing data on the occurrence of green algae $[21,29,50,67]$ or in situ observations. For a description of the lakes, see [22, 68, 69]. Thermal springs of Agkistro are located in the homonymous village, the northernmost village of Serres (N. Greece) and they feed the area's thermal spa facilities, dating back to $925 \mathrm{AD}$ [70]. The hot spring water $\left(40{ }^{\circ} \mathrm{C}\right)$ is characterized as meteoric, sterile, oligometallic, sodium, calcium, sulphate, oxycarbonate, potassium, fluoride, hypotonic, thermal water [71, 72]. Strains were isolated on solid growth media using classical 
Table 3 PCR primers used in the analyses of green-algae strains isolated from freshwaters of Greece

\begin{tabular}{|c|c|c|c|c|c|}
\hline Primer & Target gene-region & Sequence $\left(5^{\prime}-3^{\prime}\right)$ & Size (bp) & References & Conditions \\
\hline EukA & \multirow[t]{3}{*}{$18 \mathrm{~S}$ rRNA } & AACCTGGTTGATCCTGCCAGT & \multirow[t]{3}{*}{1750} & [78] & \multirow{3}{*}{$\begin{array}{l}\text { Initial denaturation step at } 95^{\circ} \mathrm{C} \text { for } 5 \text { min, } 35 \\
\text { Cycles consisting of denaturation at } 95^{\circ} \mathrm{C} \text { for } \\
60 \mathrm{~s} \text {, annealing at } 55^{\circ} \mathrm{C} \text { for } 60 \mathrm{~s} \text { and elongation } \\
\text { at } 72^{\circ} \mathrm{C} \text { for } 90 \mathrm{~s} \text {; a final } 7 \text {-min elongation step at } \\
72^{\circ} \mathrm{C} \text { was included }\end{array}$} \\
\hline EukB & & TGATCCTTCTGCAGGTTCACCTAC & & & \\
\hline U1391R & & GGGCGGTGTGTACAARGR & & {$[79]$} & \\
\hline ITS-AF & \multirow[t]{2}{*}{ ITS } & CGTTTCCGTAGGTGAACCTGC & 700 & {$[80]$} & \multirow{4}{*}{$\begin{array}{l}\text { Initial denaturation step at } 94^{\circ} \mathrm{C} \text { for } 4 \text { min, } 35 \\
\text { Cycles consisting of denaturation at } 95^{\circ} \mathrm{C} \text { for } \\
60 \mathrm{~s} \text {, annealing at } 58^{\circ} \mathrm{C} \text { for } 2 \text { min and elongation } \\
\text { at } 72^{\circ} \mathrm{C} \text { for } 2 \text { min; a final } 7 \text {-min elongation step } \\
\text { at } 72^{\circ} \mathrm{C} \text { was included }\end{array}$} \\
\hline ITS-BR & & CATATGCTTAAGTTCAGCGGG T & & \multirow{3}{*}[81]{} & \\
\hline$r b c L 1-20$ & \multirow[t]{2}{*}{ rbcl } & ATGGTTCCACAAACAGAAAC & \multirow[t]{2}{*}{1100} & & \\
\hline rbcL1181-1160 & & AAGATTTCAACTAAAGCTGGCA & & & \\
\hline
\end{tabular}

microbiological techniques and grown as batch clonal unialgal cultures [73]. The algal strains are deposited in Aristotle University of Thessaloniki MicroAlgae and Cyanobacteria Culture Collection (TAU-MAC) [74] and can be accessed at [75].

Strains were cultured in BG-11 medium with nitrogen [76] and maintained in the same medium by regular subculturing every 2 weeks. Cultures were grown as liquid batch cultures at a photosynthetic photon flux density of $20 \mu \mathrm{mol} \mathrm{m} \mathrm{m}^{-2} \mathrm{~s}^{-1}$ using cool white light fluorescent tubes (Sylvania Standard F36W/154-T8, SLI) at $20 \pm 2{ }^{\circ} \mathrm{C}$ in culture room, in a 16:8 h light:dark cycle.

\section{Light microscopy and morphology}

A Zeiss Axio Imager.Z2 (Carl Zeiss, Germany) microscope using bright field and differential interference contrast was used. Microphotographs were taken with an Axio Cam MRc5 digital camera (Carl Zeiss, Germany). Strains were identified using special taxonomic papers $[35,37,38,46,48,51,52,56,57,61]$. Mean cell dimensions were calculated after measuring the dimension of at least 50 cells of each strain.

\section{DNA extraction and PCR}

The protocol described in Atashpaz et al. [77] was used to extract DNA from algae. PCR was carried out using the primer pairs and under the conditions described in Table 3. Thermal cycling was carried out using an Eppendorf MasterCycler Pro (Eppendorf). The PCR products were visualized on a $1.2 \% \mathrm{w} / \mathrm{v}$ agarose gel in $1 \times$ TAE buffer under UV light, and were purified using the Nucleospin ${ }^{\circledR}$ Gel and PCR Clean-up kit (MACHEREY-NAGEL).

\section{Analysis of sequence data}

For each individual strain, forward and reverse reads were assembled and the assembled sequences were checked for chimeras using the RDPII chimera detection [82]. Sequence data were visually inspected using BioEdit (Ibis Biosciences $1997-2015^{\circ}$ ) and the sequences were edited manually, where necessary. For the detection of closest relatives, all sequences were compared with the BLAST function [83] and aligned with sequences obtained from GenBank [84] databases, using the ClustalW [85] alignment utility through MEGA6 software [86]. Phylogenetic analyses were performed using maximum parsimony (MP) and maximum likelihood (ML) methods implemented in MEGA6 and the confidence of the tree topologies was checked using bootstrap analyses (1000 replicates). Using the jModelTest 0.1.1 [87], the GTR+I+G model was determined as the most appropriate and was used for all ML and BI analyses (18S rRNA, ITS, $r b c L$ ). Bayesian phylogenetic analyses were also performed using MrBayes 3.2.1 [88] with 10,000,000 generations of Markov chain Monte Carlo iterations (MCMC), discarding the first 25\% as burn-in and the following datasets were sampled every 1000 th generation. The nucleotide sequences of the partial 18S rRNA, ITS and $r b c L$ gene regions from chlorophyta strains in this study were deposited in GenBank with accession numbers MK496891-MK496899, MK496922MK496931 and MK503332-MK503335, respectively.

\section{Acknowledgements \\ UL would like to sincerely acknowledge a grant by the European Union and Greek national funds through the Operational Program Competitiveness, Entrepreneurship and Innovation, under the call Research-Create-Innovate "Bioconversion of $\mathrm{CO}_{2}$ into high-added value bioproducts through sustainable microalgae cultivation processes". We thank Manthos Panou for the isolation of strain TAU-MAC 0215.}

\section{Authors' contributions}

SG conceived and designed the study, carried out sampling and strain isolation. UL performed the experiments, obtained and analyzed data and wrote the manuscript, SG contributed to manuscript preparation. Both authors read and approved the final manuscript.

\section{Funding}

Not applicable.

\section{Availability of data and materials}

The algal strains are deposited in Aristotle University of Thessaloniki MicroAlgae and Cyanobacteria Culture Collection (TAU-MAC) and can be accessed at [75]. The datasets used and/or analyzed are included in this manuscript.

Ethics approval and consent to participate

Not applicable. 


\section{Consent for publication}

Not applicable.

\section{Competing interests}

The authors declare that they have no competing interests.

Received: 26 March 2019 Accepted: 18 October 2019 Published online: 30 October 2019

\section{References}

1. Leliaert F, Smith DR, Moreau H, Herron MD, Verbruggen H, Delwiche CF, et al. Phylogeny and molecular evolution of the Green Algae. Crit Rev Plant Sci. 2012;31:1-46.

2. Fučíková K, Leliaert F, Cooper ED, Škaloud P, D'Hondt S, De Clerck O, et al. New phylogenetic hypotheses for the core Chlorophyta based on chloroplast sequence data. Front Ecol Evol. 2014. https://doi.org/10.3389/ fevo.2014.00063.

3. Guiry MD. How many species of Algae there? J Phycol. 2012;48:1057-63.

4. Zou S, Fei C, Wang C, Gao Z, Bao Y, He M, et al. How DNA barcoding can be more effective in microalgae identification: a case of cryptic diversity revelation in Scenedesmus (Chlorophyceae). Sci Rep. 2016;6:36822.

5. Zou S, Fei C, Song J, Bao Y, He M, Wang C. Combining and comparing coalescent, distance and character-based approaches for barcoding microalgaes: a test with Chlorella-like species (Chlorophyta). PLoS ONE. 2016. https://doi.org/10.1371/journal.pone.0153833.

6. Hall JD, Fučíková K, Lewis LA, Karol KG. An assessment of proposed DNA barcodes in freshwater green algae. Cryptogam Algol. 2010;31:529-55.

7. Mallet J. Genetics of speciation. In: Fox WC, Wolf BJ, editors. Evolutionary genetics: concepts and case studies. Oxford: Oxford University Press; 2006. p. 367-73.

8. Hegewald EH. Taxonomy and phylogeny of Scenedesmus. Algae. 1997;12:235-46.

9. McManus HA, Lewis LA. Molecular phylogenetic relationships in the freshwater family Hydrodictyaceae (Shaeropleales, Chlorophyceae), with an emphasis on Pediastrum duplex. J Phycol. 2011;47:152-63.

10. Ruhfel BR, Gitzendanner MA, Soltis PS, Soltis DE, Burleigh JG. From algae to angiosperms -inferring the phylogeny of green plants (Viridiplantae) from 360 plastid genomes. BMC Evol Biol. 2014;14:23.

11. Krienitz $L$, Bock C. Present state of the systematics of planktonic coccoid green algae of inland waters. Hydrobiologia. 2012;698:295-326.

12. Barinova SS, Anissimova OV, Nevo E, Jarygin MM, Wasser SP. Diversity and ecology of algae from the Nahal Qishon river, northern Israel. Plant Biosyst. 2004;138:245-59.

13. Fadel A, Atoui A, Lemaire BJ, Vinçon-leite B, Slim K. Environmental factors associated with phytoplankton succession in a Mediterranean reservoir with a highly fluctuating water level. Environ Monit Assess. 2015;187:633.

14. Padedda MB, Sechi N, Lai GG, Mariani MA, Pulina S, Sarria M, et al. Consequences of eutrophication in the management of water resources in Mediterranean reservoirs: a case study of Lake Cedrino (Sardinia, Italy). Glob Ecol Conserv. 2017;12:21-35

15. Guccione A, Biondi N, Sampietro G, Rodolfi L, Bassi N, Tredici MR. Chlorella for protein and biofuels: from strain selection to outdoor cultivation in a Green Wall Panel photobioreactor. Biotechnol Biofuels. 2014;7:84.

16. Pereira H, Gangadhar KN, Schulze PSC, Santos T, de Sousa CB, Schueler LM, et al. Isolation of a euryhaline microalgal strain, Tetraselmis sp. CTP4, as a robust feedstock for biodiesel production. Sci Rep. 2016. https://doi. org/10.1038/srep35663.

17. Legakis A, Constantinidis T, Petrakis PV. Biodiversity in Greece. In: Pullaiah T, editor. Global biodiversity, Vol. 2, selected countries in Europe. 1st ed. Oakville: Apple Academic Press; 2018.

18. Manousis T, Kontadakis C, Mbazios G, Polyzoulis G. The family Raphitomidae (Mollusca: Gastropoda: Conoidea) in the Greek seas with the description of two new species. J Biol Res Thessalon. 2018;25:14.

19. Bravakos P, Kotoulas G, Skaraki K, Pantazidou A, Economou-Amilli A. A polyphasic taxonomic approach in isolated strains of Cyanobacteria from thermal springs of Greece. Mol Phylogenet Evol. 2016:98:147-60.

20. Konstantinou D, Voultsiadou E, Panteris E, Zervou S-K, Hiskia A, Gkelis S. Leptothoe, a new genus of marine cyanobacteria (Synechococcales) and three new species associated with sponges from the Aegean Sea. J Phycol. 2019;55:882-97.

21. Genitsaris S, Kormas KA, Moustaka-Gouni M. Microscopic eukaryotes living in a dying lake (Lake Koronia, Greece). FEMS Microbiol Ecol. 2009;69:75-83.

22. Gkelis S, Panou M, Chronis I, Zervou S-K, Christophoridis C, Manolidi K, et al. Monitoring a newly re-born patient: water quality and cyanotoxin occurrence in a reconstructed shallow Mediterranean lake. Adv Oceanogr Limnol. 2017:8:33-51.

23. Chantzistrountsiou X, Tzovenis I, Parmakelis A, Economou-Amilli A. Characterization of Tetraselmis verrucosa f. rubens (Chlorodendrophyceae) strains from coastal lagoons of Western Greece using a multivariate approach. Phytotaxa. 2016;278:225-40.

24. Chrisostomou A, Moustaka-Gouni M, Sgardelis S, Lanaras T. Air-dispersed phytoplankton in a Mediterranean river-reservoir system (AliakmonPolyphytos, Greece). J Plankton Res. 2009;31:877-84.

25. Michaloudi E, Moustaka-Gouni M, Gkelis S, Pantelidakis K. Plankton community structure during an ecosystem disruptive algal bloom of Prymnesium parvum. J Plankton Res. 2009;31:301-9.

26. Genitsaris S, Kormas KA, Moustaka-Gouni M. Airborne algae and cyanobacteria: occurrence and related health effects. Front Biosci. 2011;3:772-87.

27. Michaloudi E, Moustaka-Gouni M, Pantelidakis K, Katsiapi M, Genitsaris S. Plankton succession in the temporary Lake Koronia after intermittent dry-out. Int Rev Hydrobiol. 2012;97:405-19.

28. Oikonomou A, Katsiapi M, Karayanni H, Moustaka-Gouni M, Kormas KA. Plankton microorganisms coinciding with two consecutive mass fish kills in a newly reconstructed lake. Sci World J. 2012;2012:504135.

29. Nikouli E, Kormas KA, Berillis P, Karayanni H, Moustaka-Gouni M. Harmful and parasitic unicellular eukaryotes persist in a shallow lake under reconstruction (L. Karla, Greece). Hydrobiologia. 2013;718:73-83.

30. Vanormelingen $P$, Hegewald E, Braband A, Kitschke M, FriedI T, Sabbe $K$, et al. The systematics of a small spineless Desmodesmus species, $D$. costato-granulatus (Sphaeropleales, Chlorophyceae), based on ITS2 rDNA sequence analyses and cell wall morphology. J Phycol. 2007;43:378-96.

31. Lürling M. Phenotypic plasticity in the green algae Desmodesmus and Scenedesmus with special reference to the induction of defensive morphology. Ann Limnol Int J Limnol. 2003;39:85-101.

32. Egan PF, Trainor FR. Phenotypic plasticity in Scenedesmus communis Hegew. (Chlorophyceae). II. Examples of algal cyclo- and nonocyclomorphosis. Am J Bot. 1991;78:37-52.

33. An SS, FriedI T, Hegewald E. Phylogenetic relationships of Scenedesmus and Scenedesmus-like coccoid green algae as inferred from ITS-2 rDNA sequence comparison. Plant Biol. 1999;1:418-28.

34. Shubert E, Wilk-Woźniak E, Ligęza S. An autecological investigation of Desmodesmus: implications for ecology and taxonomy. Plant Ecol Evol. 2014;147:202-12.

35. Hegewald E, Schmidt A, Schnepf E. Revision of the Desmodesmus species with lateral spines. 1. Desmodesmus subspicatus (R. Chod.) E. Hegew. et A. Schmidt. Arch Hydrobiol Suppl Algol Stud. 2001;101:1-26.

36. Hegewald E, Silva PC. Annotated catalogue of Scenedesmus and nomenclaturally related genera, including original descriptions and figures. Berlin: J. Cramer; 1988.

37. Hegewald E, Schnepf E. Scenedesmus abundans (Kirchn.) Chod., an older name for Chlorella fusca SHIH. et KRAUSS. Arch für Protistenkd. 1991;139:133-76.

38. Hegewald EH. New combinations in the genus Desmodesmus (Chlorophyceae, Scenedesmaceae). Arch Hydrobiol Suppl Algol Stud. 2000:96:1-18.

39. Khan SA, Rashmi, Hussain MZ, Prasad S, Banerjee UC. Prospects of biodiesel production from microalgae in India. Renew Sustain Energy Rev. 2009;13:2361-72

40. Bhatt NC, Tamta S. Integration of microalgae cultivation with wastewater for sustainable biofuel production. Curr Sci. 2013;105:749.

41. Lee K, Eisterhold ML, Rindi F, Palanisami S, Nam PK. Isolation and screening of microalgae from natural habitats in the midwestern United States of America for biomass and biodiesel sources. J Nat Sci Biol Med. 2014;5:333-9.

42. Hegewald E, Schmidt A, Braband A, Tsarenko P. Revision of the Desmodesmus (Sphaeropleales, Scenedesmaceae) species with lateral spines. 2. The multi-spined to spineless taxa. Arch Hydrobiol Suppl Algol Stud. 2005;116:1-38. 
43. Gkelis S, Papadimitriou T, Zaoutsos N, Leonardos I. Anthropogenic and climate-induced change favors toxic cyanobacteria blooms: evidence from monitoring a highly eutrophic, urban Mediterranean lake. Harmful Algae. 2014;39:322-33.

44. Gorelova OA, Baulina OI, Solovchenko AE, Chekanov KA, Chivkunova OB, Fedorenko TA, et al. Similarity and diversity of the Desmodesmus spp. microalgae isolated from associations with White Sea invertebrates. Protoplasma. 2015;252:489-503.

45. Kaplan-Levy RN, Alster-Gloukhovski A, Benyamini Y, Zohary T. Lake Kinneret phytoplankton: integrating classical and molecular taxonomy. Hydrobiologia. 2016;764:283-302.

46. Bica A, Bardu-Tudoran B, Drugă B, Coman C, Nicoară A, Szöke-Nagy T, et al. Desmodesmus communis (Chlorophyta) from Romanian freshwaters: coenobial morphology and molecular taxonomy based on the ITS2 of new isolates. Ann RSCB. 2012;17:16-28.

47. Nozaki H, Onishi K, Morita E. Differences in pyrenoid morphology are correlated with differences in the $r b c L$ genes of members of the Chloromonas lineage (Volvocales, Chlorophyceae). J Mol Evol. 2002;55:414-30.

48. Hegewald E. Scenedesmus communis Hegewald, a new species and its relation to Scenedesmus quadricauda (Turp.) Bréb. Algol Stud für Hydrobiol. 1977;19:142-55.

49. Kagalou I, Leonardos I. Typology, classification and management issues of Greek lakes: implication of the Water Framework Directive (2000/60/ EC). Environ Monit Assess. 2009;150:469-84.

50. Temponeras M, Kristiansen J, Moustaka-Gouni M. Seasonal variation in phytoplankton composition and physical-chemical features of the shallow Lake Doïrani, Macedonia, Greece. Hydrobiologia. 2000;424:109-22.

51. Beyerinick MW. Culturversuche mit Zoochlorellen, Lichenengonidien und anderen niederen Algen. Bot Zeitung. 1890:47:725-39, 741-54, 757-68, 781-5.

52. Shihira I, Krauss RW. Chlorella: physiology and taxonomy of forty-one isolates. College Park: University of Maryland; 1965.

53. Krienitz L, Huss VAR, Bock C. Chlorella: 125 years of the green survivalist. Trends Plant Sci. 2015;20:67-9.

54. Petaloti C, Voutsa D, Samara C, Sofoniou M, Stratis I, Kouimtzis T. Nutrient dynamics in shallow lakes of Northern Greece. Environ Sci Pollut Res Int. 2004;11:11-7.

55. Genitsaris S, Moustaka-Gouni M, Kormas KA. Airborne microeukaryote colonists in experimental water containers: diversity, succession, life histories and established food webs. Aquat Microb Ecol. 2011;62:139-52.

56. Lee WK. Uronema trentonense sp. nov. (Chlorophycophyta, Ulotrichales): a new edaphic alga from New Jersey. Phycologia. 1978;17:191-5.

57. Mattox KR, Bold HC. III. Taxonomy of certain Ulothrichacean algae. In: Phycological Studies. Texas: The university of Texas publication; 1962. p. 18-28.

58. Caisová L, Melkonian M. The Chaetophorales (Chlorophyceae)—a taxonomic revision at family level. Eur J Phycol. 2018;53:381-92.

59. Spartinou M-GD. The Microflora of Lake Amvrakia, Western Greece. A systematic and ecological approach, Ph.D. Thesis, National and Kapodistrian University of Athens; 1992.

60. Qiao K, Takano T, Liu S. Discovery of two novel highly tolerant $\mathrm{NaHCO}_{3}$ trebouxiophytes: identification and characterization of microalgae from extreme saline-alkali soil. Algal Res. 2015;9:245-53.

61. Temraleeva A, Moskalenko S, Mincheva E, Bukin Y, Sinetova M. Spongiosarcinopsis terrestris gen. et sp. nov. (Chlorophyta, Chlorophyceae): a new genus of green algae from gray forest soil, Russia. Phytotaxa. 2018;376:291-300

62. Fawley MW, Fawley KP, Buchheim MA. Molecular diversity among communities of freshwater microchlorophytes. Microb Ecol. 2004:48:489-99.

63. Buchheim MA, Lemieux C, Otis C, Gutell RR, Chapman RL, Turmel M. Phylogeny of the Chlamydomonadales (Chlorophyceae): a comparison of ribosomal RNA gene sequences from the nucleus and the chloroplast. Mol Phylogenet Evol. 1996;5:391-402.

64. Roy S, Tyagi A, Shukla V, Kumar A, Singh UM, Chaudhary LB, et al. Universal plant DNA barcode loci may not work in complex groups: a case study with Indian Berberis species. PLoS ONE. 2010;5:e13674.

65. Bafeel SO, Arif IA, Bakir MA, Khan HA, Al Farhan AH, Al Homaidan AA, et al. Comparative evaluation of PCR success with universal primers of maturase K (matK) and ribulose-1, 5-bisphosphate carboxylase oxygenase large subunit $(r b c L)$ for barcoding of some arid plants. Plant Omics J. 2011:4:195-8.

66. Gkelis S, Zaoutsos N. Cyanotoxin occurrence and potentially toxin producing cyanobacteria in freshwaters of Greece: a multi-disciplinary approach. Toxicon. 2014;78:1-9.

67. Moustaka-Gouni M, Vardaka E, Tryfon E. Phytoplankton species succession in a shallow Mediterranean lake (L. Kastoria, Greece): steady-state dominance of Limnothrix redekei, Microcystis aeruginosa and Cylindrospermopsis raciborskii. Hydrobiologia. 2007;575:129-40.

68. Vardaka E, Moustaka-Gouni M, Cook CM, Lanaras T. Cyanobacterial blooms and water quality in Greek waterbodies. J Appl Phycol. 2005;17:391-401.

69. Fytianos K, Lourantou A. Speciation of elements in sediment samples collected at Lakes Volvi and Koronia, N. Greece. Environ Int. 2004;30:11-7.

70. Efstathiadis I. Agistro. 2019. https://www.agistro.com/.

71. Fytikas M, Andritsos N, Karydakis G, Kolios N, Mendrinos D, Papachristou M. Geothermal exploration and development activities in Greece during 1995-1999. In: Proceedings world geotherm congress. 2000. p. 199-208.

72. Karydakis G, Arvanitis A, Andritsos N, Fytikas M. Low enthalpy geothermal fields in the Strymon basin (Northern Greece). In: Proceedings world geothermal congress. Turkey; 2005.

73. Gkelis S, Tussy PF, Zaoutsos N. Isolation and preliminary characterization of cyanobacteria strains from freshwaters of Greece. Open Life Sci. 2015;10:52-60.

74. Gkelis S, Panou M. Capturing biodiversity: linking a cyanobacteria culture collection to the "scratchpads" virtual research environment enhances biodiversity knowledge. Biodivers Data J. 2016;4:e7965.

75. Gkelis S. Aristotle University of Thessaloniki MicroAlgae and Cyanobacteria Culture Collection (TAU-MAC). 2019. http://cyanobacteria.myspecies.info/.

76. Rippka R. Isolation and purification of Cyanobacteria. Methods Enzymol. 1988;167:3-27.

77. Atashpaz S, Khani S, Barzegari A, Barar J, Vahed SZ, Azarbaijani R, et al. A robust universal method for extraction of genomic DNA from bacterial species. Microbiology. 2010;79:538-42.

78. Medlin L, Elwood HJ, Stickel S, Sogin ML. The characterization of enzymatically amplified eukaryotic 16S-like rRNA-coding regions. Gene. 1988;71:491-9.

79. Lane D. 16S/23S rRNA sequencing. In: Stackebrandt E, Goodfellow $\mathrm{M}$, editors. Nucleic acid techniques in bacterial systematic. New York: Wiley; 1991. p. 115-75.

80. Johnson JL, Fawley MW, Fawley KP. The diversity of Scenedesmus and Desmodesmus (Chlorophyceae) in Itasca State Park, Minnesota, USA. Phycologia. 2007;46:214-29.

81. Nozaki H, Itoh M, Sano R, Uchida H, Watanabe MM, Kuroiwa T. Phylogenetic relationships within the colonial Volvocales (Chlorophyta) inferred from rbcL gene sequence data. J Phycol. 1995;31:970-9.

82. Maidak BL, Cole JR, Lilburn TG, Parker CT, Saxman PR, Farris RJ, et al. The RDP-II (Ribosomal Database Project). Nucleic Acids Res. 2001;29:173-4.

83. National Center for Biotechnology Information-Basic Local Alignment Search Tool. 2019. http://www.ncbi.nlm.nih.gov/BLAST/.

84. National Center for Biotechnology Information-GenBank. 2019. http://www.ncbi.nlm.nih.gov.

85. Thompson JD, Higgins DG, Gibson TJ. CLUSTAL W: improving the sensitivity of progressive multiple sequence alignment through sequence weighting, position-specific gap penalties and weight matrix choice. Nucleic Acids Res. 1994;22:4673-80.

86. Tamura K, Stecher G, Peterson D, Filipski A, Kumar S. MEGA6: molecular evolutionary genetics analysis version 6.0. Mol Biol Evol. 2013;30:2725-9.

87. Posada D. jModelTest: phylogenetic model averaging. Mol Biol Evol. 2008;25:1253-6.

88. Ronquist F, Teslenko M, Van Der Mark P, Ayres DL, Darling A, Hohna S, et al. MrBayes 3.2: efficient Bayesian phylogenetic inference and model choice across a large model space. Syst Biol. 2012;61:539-42.

\section{Publisher's Note}

Springer Nature remains neutral with regard to jurisdictional claims in published maps and institutional affiliations. 